\title{
EQUALITY RIGHTS AND THE ALLOCATION OF SCARCE RESOURCES IN HEALTH CARE: A COMMENT ON CAMERON V. NOVA SCOTIA
}

\author{
Barbara von Tigerstrom
}

On 14 September 1999, the Nova Scotia Court of Appeal released its decision in Cameron v. Nova Scotia (Attorney General), ${ }^{1}$ unanimously upholding the decision of the trial judge ${ }^{2}$ that the province's failure to fund in vitro fertilization (IVF) and intra cytoplasmic sperm injection (ICSI, a variant of IVF) does not violate the Canadian Charter of Rights and Freedoms.

The case is an important one for a number of reasons. The funding of innovative medical technologies and treatments will continue to be a contentious issue as the availability of a growing array of new and often expensive modalities challenges those responsible for allocating limited health care budgets in a fair and efficient manner. ${ }^{3}$ As a result, clarification of the legal framework for the equitable allocation of resources in this context is an important endeavour of more than academic interest. In addition, the decision raises a

Cameron v. Nova Scotia (Attorney General) (1999), 177 D.L.R. (4t) 611; [1999] N.S.J. No. 297 (QL) [hereinafter Cameron (CA), cited to D.L.R.].

2 Cameron v. Nova Scotia (Attorney General) (1999), 172 N.S.R. (2d) 227; [1999] N.S.J. No. 33 (N.S, S.C.) (QL) [hereinafter Cameron (NSSC), cited to N.S.R.].

3 Controversies surrounding allocation of resources in health care have given rise to a number of legal claims in Canada; past cases include Brown y. British Columbia (Minister of Health) (1990), 66 D.L.R. (4 $4^{\text {th }}$ 444; Ontario Nursing Home Assn. v. Ontario (1990), 72 D.L.R. $\left(4^{\text {th }}\right) 166$ and Eldridge v. British Columbia (Attorney General), [1997] 3 S.C.R. 624, and there have been recent reports of a legal challenge in Ontario regarding funding for programs for autistic children (see "Parents sue for right to autism therapy" The Globe and Mail (25 November 1999) A7.) Similar issues have often received media attention as well: see e.g. C. Abraham, "Breast-cancer drug creates cost dilemma" The Globe and Mail (17 August 1999) Al; "Cancer treatment curbs "costing lives"' BBCNews (21 October 1999), online: BBC News Homepage < http://news. bbc.co.uk/hi/english/uk/scotland/newsid_481000/ 481057.stm>. number of potentially significant questions of Charter interpretation; for example, what is the meaning of "disability" in section 15(1) and when, if at all, may a shortage of resources be sufficient to justify an infringement under section 1? As one of the first appellate decisions to apply the Supreme Court of Canada's decision in Law v. Canada (Minister of Employment and Immigration $),{ }^{4}$ the reasons of the Nova Scotia Court of Appeal both demonstrate the utility of Law's restatement of principles and remind us that there are still many unresolved questions in the interpretation of "the Charter's most conceptually difficult provision."

\section{FACTS}

The appellants, Alexander Cameron and Cheryl Smith, have not been able to conceive because of "severe male factor infertility." After several other procedures were unsuccessful, the appellants' physicians referred them for ICSI, a variant of IVF in which the sperm is implanted in the egg and which has been more successful in cases of male factor infertility than conventional IVF. Four cycles of ICSI, two in Toronto and two in Calgary, were unsuccessful. At the relevant time ICSI was not available in Nova Scotia. The appellants claimed reimbursement of the medical hospital costs of these procedures (amounting to $\$ 23,402.00$ ) from the Nova Scotia Health Care Insurance Plan (the "Plan"), but were informed that IVF and ICSI were not insured procedures.

4 Law v. Canada (Minister of Employment and Immigration), [1999] 1 S.C.R. 497, 170 D.L.R. (4*) 1 [hereinafter Law, cited to D.L.R.].

$5 \quad$ lbid. at 6. 
The legislation governing public health insurance in Nova Scotia is the Health Services and Insurance Act. ${ }^{6}$ This Act creates two categories of insured services: "insured medical services" which are services provided by physicians and "insured hospital services" which include all other services (e.g. diagnostic or laboratory services) delivered on an inpatient or outpatient basis. Section 3 of the Act establishes the right to receive insured hospital services and the right to insurance for the cost of insured medical services to the extent of the tariffs established by the Province. Payment for insured hospital services provided to Nova Scotia residents in other provinces is also provided for in regulations under the Act, in accordance with bilateral agreements with other provinces. ${ }^{7}$ The key aspect of the legislative scheme, for our purposes, is that hospital or medical services that are "medically required" are insured services.

Insured medical services are further subject to tariffs which are set by a process of joint review and negotiation by the Minister (formerly the Health Services and Insurance Commission) and the provincial Medical Society. ${ }^{8}$ The total amount of the tariffs is limited by a cap system which means that new fees or services may be introduced only at the expense of existing ones. ${ }^{9}$

Some medical procedures relating to the diagnosis and treatment of infertility are covered by the Plan, but IVF is not covered in Nova Scotia or elsewhere in Canada except Ontario, where limited coverage is available in certain cases. ${ }^{10}$ IVF is expressly excluded under Nova Scotia's agreements with other provinces for reimbursement of services.

The appellants, in addition to seeking reimbursement of the costs of their procedures, sought a declaration that IVF and ICSI are insured services under the Act. They also sought punitive damages and an order directing the Minister to establish a tariff for payment of IVF and ICSI procedures.

\footnotetext{
R.S.N.S. 1989 , c. 197 [hereinafter the "Act"]

Cameron (NSSC), supra note 2 at 237.

lbid.

Ibid. at 236; Cameron (CA), supra note 1 at 624.

Cameron (CA), supra note 1 at 618. In Ontario, three cycles of IVF are covered when the female partner has total bilateral blockage of the Fallopian tubes (ibid.). The Canadian armed forces also reportedly pays for IVF in similar cases; A. Leader, "New reproductive technologies: Why are we limiting choices for infertile couples?" (1999) 161 CMAJ 1411 at 1411 .
}

\section{DECISION OF THE NOVA SCOTIA SUPREME COURT}

Although the plaintiffs did not use conventional IVF, they were granted standing to challenge the failure to cover IVF and ICSI. They advanced a twofold argument: first, that under the Act and applicable regulations, as properly interpreted, IVF and ICSI must be insured services and therefore the denial of coverage was unlawful; and second, that the Province's refusal to provide coverage violated their rights under the Charter. Specifically, the plaintiffs argued that the refusal breached the Charter because it discriminated against them on the basis of physical disability. An argument that the denial of coverage also constituted a violation of their section 7 rights was summarily dismissed at trial ${ }^{11}$ and was not pursued on appeal.

At trial, Kennedy C.J.S.C., after reviewing the complex legislative structure of the Plan, addressed the plaintiffs' argument that IVF and ICSI are "medically required" and must be covered under the Province's law. He held that IVF and ICSI are not "medically required" or "medically necessary," despite being "medically indicated" or "standard medical procedure."12 In making this determination, he noted that other options existed, that the success rate of the procedures was limited and that there were risks inherent in the procedures. ${ }^{13}$

The plaintiffs claimed that denial of payment for these procedures constitutes a denial of equal benefit under the law in violation of section 15(1) of the Charter. However, Kennedy C.J.S.C. held that the decision not to fund IVF and ICSI was based on the nature of the treatments, not the personal characteristics of those seeking the treatments. The procedures simply failed to meet the criteria necessary for coverage. As a result, it was not necessary to determine whether infertility could be classified as a disability or as an analogous ground under section 15(1). There was no discrimination against the plaintiffs and thus no breach of section 15(1). 


\section{DECISION OF THE NOVA SCOTIA COURT OF APPEAL}

The Justices of the Nova Scotia Court of Appeal were unanimous in their conclusion that the appeal should be dismissed, but differed in their reasoning. Chipman J.A., with whom Pugsley J.A. concurred, was of the opinion that there was a violation of section $15(1)$, but that it was justified under section 1 , while Bateman J.A. found no violation.

\section{Judgment of Chipman J.A., Pugsley J.A. Concurring}

The first question to be addressed was whether IVF and ICSI were insured services under the Act. All three justices $^{14}$ agreed that the trial judge had not erred in finding that these were not insured services. The services were not insured either as out-of-province hospital services or as insured hospital or medical services within the province unless they were "medically required." The appellants failed to establish that the trial judge had erred in finding that the services were not medically required.

The analysis of this point required the court to consider the meaning of "medically required" or "medically necessary."15 Chipman J.A. rejected Kennedy C.J.S.C.'s narrow interpretation of medically necessary which required a "medical end" and therefore excluded procedures which were directed to the nonmedical end of having a child. He also dismissed the argument that the existence of other choices meant that the procedures were not medically necessary. Therefore, the procedures "could qualify as being medically necessary." ${ }^{16}$ However, considering a number of factors, including costs, success rates and risks, the finding that IVF and ICSI "were not shown to be medically required, as a matter of interpretation of the Act, the Regulations and the administration of the policy has not been shown to be in error."17

14 Bateman J.A. agreed with the two other judges on this first question and only delivered separate concurring reasons dealing with the Charter issue; see Cameron ( $\mathrm{CA})$, supra note 1 at 669 .

is Both Kennedy C.J.S.C. and Chipman J.A. treated the two terms as equivalent and interchangeable; see ibid. at 631

16 Ibid. at 634 [emphasis in original]

17 lbid. at 636
In reaching this conclusion, Chipman J.A. also rejected the appellants' argument that coverage for services must be "comprehensive" in the sense of being "all-inclusive;" rather, he said, coverage is limited to treatments that are medically required in the judgement of those administering the scheme. ${ }^{18}$ As long as their decisions are made in good faith, comply with the Charter and are not "clearly wrong," the courts have no jurisdiction to overturn them. ${ }^{19}$

Chipman J.A. then turned to consider the Charter argument. The analysis of section 15(1) was based on the recently released decision of the Supreme Court of Canada in Law, which set out a three-step analysis: ${ }^{20}$

(a) Does the impugned law (a) draw a formal distinction between the claimant and others on the basis of one or more personal characteristics, or (b) fail to take into account the claimant's already disadvantaged position within Canadian society resulting in substantively differential treatment between the claimant and others on the basis of one or more personal characteristics?

(b) Is the claimant subject to differential treatment based on one or more enumerated and analogous grounds?

and

(c) Does the differential treatment discriminate, by imposing a burden upon or withholding a benefit from the claimant in a manner which reflects the stereotypical application of presumed group or personal characteristics, or which otherwise has the effect of perpetuating or promoting the view that the individual is less capable or worthy of recognition or value as a human being or as a member of Canadian society, equally deserving of concern, respect, and consideration?

\footnotetext{
Ibid, at 637 .

Ibid. at 638-39.

Law, supra note 4 at 38 .
} 
This inquiry is to be undertaken using a comparative approach $^{21}$ and taking account of contextual factors including pre-existing disadvantage, the relationship between the grounds and the claimant's characteristics or circumstances, the ameliorative purpose or effects of the impugned provision and the nature of the interest affected. ${ }^{22}$ It is also to be purposive, requiring the claimant to show that the purpose of section 15 has been infringed by the impugned law, ${ }^{23}$

The argument of the appellants was that the denial of coverage for IVF and ICSI amounted to discrimination on the basis of the personal characteristic of infertility. Chipman J.A. was of the opinion that the Act and the Province's policy were neutral on their face, and he therefore turned to the question whether there is distinction in the impact of the policy based on a personal characteristic of the appellants. ${ }^{24}$

Chipman J.A. found that there was a distinction between the fertile, who had unrestricted access to a "full array of services for reproduction" and the infertile, who did not have such access. ${ }^{25}$ Although certain services for infertility were covered under the Plan, the infertile were denied access to a medically recommended, appropriate treatment, and thus were unequally treated.

Having found this distinction, Chipman J.A. also held that it was based on an enumerated ground, since he found that infertility is a disability. ${ }^{26}$ This brought him to the third question, whether the distinction constituted discrimination. Again, he concluded in the affirmative. Considering the four factors referred to in Law, he focused on the first, the presence of a preexisting disadvantage. In this context, the negative view of infertile persons historically and by some members of society, and the social stigma and personal trauma that can result from infertility, led him to conclude that although the infertile do not suffer disadvantage to the same extent as some disabled persons, they are subject to a pre-existing disadvantage. ${ }^{27}$ Finally, he concluded that the "impact of the denial of these procedures to the infertile perpetuates the view that they are less worthy

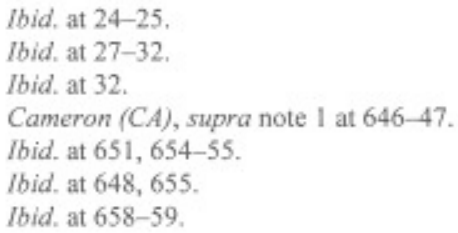

of recognition or value. It touches their essential dignity and self-worth. ${ }^{328}$ Therefore, the third part of the test was also satisfied, and he found that there was a violation of the appellants' section $15(1)$ rights.

In Chipman J.A.'s opinion, however, the violation could be justified as a reasonable limit under section 1 . In undertaking the section 1 analysis, he noted that it must be conducted flexibly, and that governments will be allowed considerable latitude in allocating scarce resources, although "the leeway granted is not infinite." 29

The objective of the policy was described as "provid[ing] the best possible health care coverage to Nova Scotians in the context of limited financial resources." ${ }^{30}$ Included within this objective are the specific objectives of cost containment and protection from potentially harmful treatments, the stated goals of the policy of denying funding for IVF and ICSI. Chipman J.A. emphasized the difficulty of the task of allocating scarce health care resources and the resulting deference which should be shown to allocation decisions. It was also relevant that the policy was not "for all time" but was a reasonable approach at present. ${ }^{31}$ After a brief review of rational connection, minimal impairment and proportionality, Chipman J.A. concluded that the policy was justified under section 1 and the appeal should therefore be dismissed. ${ }^{32}$

\section{Judgment of Bateman J.A.}

Bateman J.A., concurring in the result, took the view that "the appellants are not, by reason of the male appellant's infertility, disabled nor is the denial of funding for the medical procedures discriminatory." There was a distinction drawn on the basis of a personal characteristic, as the lack of funding did have an adverse effect on the appellants due to their infertility. ${ }^{34}$ However, the differential treatment, according to Bateman J.A., was not based on an enumerated or analogous ground, if interpreted in a purposive and contextual manner. After reviewing statements of the Supreme Court of Canada on the subject of disability, she concluded that although infertility could be viewed as a disability in some contexts, whatever suffering the

\footnotetext{
Ibid. at 660 .

Ibid. at 663-64.

Ibid. at 664 .

Ibid. at 667-68.

Ibid. at $668-69$.

Ibid. at 669 .

Ibid. at 671-72.
} 
appellants experienced as a result of the condition did not compare to the marginalization common to other disabilities. ${ }^{35}$ Nor could infertility be considered an analogous ground, ${ }^{36}$

Although the analysis could have ended there, Bateman J.A. went on to explain that even if infertility could have constituted an enumerated or analogous ground, the appellants had failed to show that the denial of funding was discriminatory. The refusal to fund these procedures under the circumstances did not "promote the view that the infertile are less capable or less worthy of value." This did not mean that a denial of funding could never constitute discrimination; in this case, however, it did not. ${ }^{37}$ Bateman J.A. found, therefore, that Kennedy C.J.S.C. had not erred in finding that the policy was not discriminatory.

\section{ANALYSIS}

\section{"Medically necessary"}

The first issue in this appeal required the Court of Appeal to confront the notoriously difficult task of defining and applying the concept of "medically necessary." This concept is of central importance in the Canadian health care system because it determines, through its inclusion in the Canada Health Act and provincial health insurance legislation, what services must be insured under public health plans. ${ }^{38} \mathrm{~A}$ comprehensive review of this subject is beyond the

\footnotetext{
Ibid. at 676 .

lbid, at 676-78.

Ibid. at $683-84$

Canada Heallh Act, R.S.C. 1985, c. C-6; the definitions of hospital services and physician services in 5.2 are qualified as those which are "medically necessary" and "medically required," respectively; these services, along with surgicaldental services, are defined as insured health services under the Act, and according to $\mathrm{s}$. 9, all "insured health services" must be insured by the provincial health care insurance plan. The provinces may (and do) insure some services which may not be "medically required" but the criterion of comprehensiveness in s. 9 of the Canada Health Act requires that at least medically required physician or hospital services must be included. The Alberta Health Care Insurance Act, R.S.A. 1980, c. A-24, for example, defines "insured services" in s. 1(n) as: "(i) all services provided by physicians that are medically required, (ii) those services that are provided by a dentist in the field of oral surgery and are specified in the regulations, and (iii) any other services that are declared to be insured services pursuant to section 2" [emphasis added].
}

scope of this comment ${ }^{39}$ but the analysis in this case raises some important questions.

For example, should the existence of alternative means be considered relevant to the judgement of necessity? Should the decision about medical necessity be a purely medical decision made by a medical professional alone or should other factors such as cost, risk and success rates enter into the decision-making process at a policy level? ${ }^{40}$ It may be increasingly difficult to separate these two kinds of decision-making.

Another important question is whether "medically necessary" procedures should be restricted to those which are medical means serving a medical end, as the respondents argued, ${ }^{41}$ and if so, how should a "medical end" be defined? Chipman J.A. expressed the view that "the end of all medical treatment is to improve the quality of life. ${ }^{n+2}$ Especially given the current emphasis on prevention, holistic health and wellness, as opposed to the mere treatment of dysfunction and disease, as the goal of health care, it is increasingly difficult to distinguish between medical and non-medical ends. The growing influence of alternative medicine and interest in "determinants of health"43 may also challenge the boundaries between medical and non-medical means. In light of these developments, we may need to undertake a reexamination of the meaning of medical necessity.

If the result of this reexamination is a broader scope of potentially insurable health care interventions, even more will be at stake in attempting to draw distinctions between those which should, in fact, be insured and those which need not be. It may be increasingly difficult to see the decision as a purely medical one without considering broader policy questions including cost effectiveness, risks, etc. In this

39 For a discussion of some of the issues surrounding the interpretation of "medically necessary" see T. A. Caulfield, "Wishful Thinking: Defining 'Medically Necessary' in Canada" (1996) 4 Health L. J. 63.

to Caulfield suggests that decisions regarding medically necessary services should consider criteria such as appropriateness and effectiveness, cost-effectiveness, the choices of the individual patient, community and individual values and ethical and legal implications. /bid. at 84 .

4 Cameron (CA), supra note 1 at 634

42 Ibid.

43 See e.g. Federal, Provincial and Territorial Advisory Committee on Population Health, Toward a Healthy Future: Second Report on the Health of Canadians (Ottawa: Health Canada, 1999). 
case, Chipman J.A. specifically rejected the arguments accepted by Kennedy C.J.S.C. at trial ${ }^{44}$ and preferred the "approach ... that in the scheme of things - in the order of priorities - these two procedures, having regard to costs, the limited success rate and the risks do not, at this time, rank sufficiently high to warrant payment for them from public funding."

This raises the further issue of how the first question of determining medical necessity relates to the second question of compliance with the Charter, and what this means for the fair allocation of scarce resources among an ever-growing pool of eligible services. Given that medical necessity is the fundamental criterion for health services to be insured, one might ask why, if it is accepted that IVF and ICSI are not medically necessary, consideration of the claim should even reach the section 15 analysis? If the procedures are not medically necessary, how can one claim that the failure to fund them is discriminatory? The answer to this may depend in part on how we define medically necessary. The Charter might, in some cases, require provinces to insure services even when they are not medically necessary by some definitions. ${ }^{46}$ Alternatively, one could argue that the interpretation of the medically necessary standard itself should take into account Charter rights. However, the same criteria that may be used to judge medical necessity, such as risk and cost-effectiveness, may play into the section 1 analysis under the Charter. The relationship between these two questions is complex and requires further investigation.

\section{Section 15}

It should be uncontroversial that the denial of funding for IVF and ICSI results in differential treatment based on the personal characteristic of infertility. Kennedy C.J.S.C.'s determination that the distinction was based on the nature of the treatments rather than a

Cameron (CA), supra note 1 at 634.

45 Ibid, at 635 .

46 For example, restriction of funding for assisted reproduction services to cases where there is a biological cause of infertility to the exclusion of, for example, same-sex couples could be a s. 15 violation. Restricting funding on the criterion of age could also attract a $\$ .15$ challenge (as has been proposed in the UK. based on evidence of declining effectiveness of the treatments for older women; see "Age limit for NHS fertility treatment" BBC News (23 August 1999) online: BBC News Homepage $<$ http://new,bbc,co,uk/hi/english/health/newsid_427000/427 $831 . \mathrm{stm}>$ ). personal characteristic effectively ignores the possibility of adverse-effect discrimination. Therefore, the first important question in the section 15 analysis is whether infertility can be considered a disability for the purposes of the Charter or, alternatively, whether it is an analogous ground. This question had not previously been considered by Canadian courts, and indeed there is little discussion in the section 15 jurisprudence as to how to define the meaning and scope of "disability."

The US case law on this question in the context of the Americans with Disabilities $\mathrm{Act}^{48}$ is divided and, although to some extent the analysis is specific to the ADA provisions, it sheds some light on the definition of "disability" and its application to infertility. ${ }^{49}$ Title I of the ADA prohibits discrimination in employment against "a qualified individual with a disability" ${ }^{30}$ and defines an "individual with a disability" as one who has "a physical or mental impairment that substantially limits one or more of the major life activities of such individual." ${ }^{, 51}$ Infertility is a physical impairment and substantially limits reproduction: the essential question is whether reproduction is a "major life activity." This term is not defined in the ADA but the Regulations to Implement the Equal Employment Provisions of the Americans with Disabilities Act give as examples "caring for oneself, performing manual tasks, walking, seeing, hearing, speaking, breathing, learning, and

47 There is some discussion of what constitutes a disability in cases considering federal and provincial human rights legislation. See e.g. Ede v. Canada (Canadian Armed Forces) (1990), 11 C.H.R.R. D/439 (Cdn. Human Rights Trib.); Ouimette v. Lily Cups Lid. (1990), 12 C.H.R.R. D/19 (Ont. Bd. Inq.); Imperial Oil Ltd. v. Ontario (Human Rights Commission) (re Entrop) (1998), 108 O.A.C. 81; [1998] O.J. No. 422 (Div. Ct.) (QL), leave to appeal granted [1998] O.J. No. 1927 (C.A.). For a discussion of some of these cases, see R. W. Zinn and P. P. Brethour, The Law of Human Rights in Canada: Practice and Procedure, looseleaf (Aurora, Ont.: Canada Law Book, 1998, updated 1999) at 5-9ff.

4842 U.S.C. $\$ \S 120101-12213$ (1988 \& Supp. IV 1992) [hereinafter ADA].

49 For a discussion of these cases, see K. C. Morgan, "Should Infertility be a Covered Disability Under the ADA?: A Question for Congress, not the Courts" (1997) 65 U. Cin. L. Rev. 963; D. K. Dallmann, "The Lay View of What 'Disability' Means Must Give Way to What Congress Says it Means: Infertility as a 'Disability' Under the Americans With Disabilities Act" (1996) 38 Wm. \& Mary L. Rev. 371; S. M. Tomkowicz, "The Disabling Effects of Infertility: Fertile Grounds for Accommodating Infertile Couples Under the Americans With Disabilities Act" (1996) 46 Syracuse L. Rev. 1051 .

s. ADA, supra note 48, \$12112(a).

51 Ibid. $\S 12102(2)(A)$. The definition of "individual with a disability" also includes those who have a record of, or are regarded as having, an impairment: $\S 12102(2)(B),(C)$. 
working." ${ }^{152}$ The Interpretive Guidance on Title I of the Americans with Disabilities Act issued by the Equal Employment Opportunity Commission (EEOC) states that major life activities are "those basic activities that the average person in the general population can perform with little or no difficulty." 53

The first decision to consider infertility under the ADA, Pacourek v. Inland Steel Co., held that reproduction could be considered a major life activity and denied the defendants' motion to dismiss on that basis. ${ }^{54}$ This conclusion was again reached in a later decision of the same court. ${ }^{55}$ However, two other courts rejected this reasoning and held that although infertility was an impairment within the meaning of the ADA, it did not substantially limit a major life activity. ${ }^{56}$ Compared with the examples of major life activities in the regulations, reproduction did not qualify; it was not engaged in with the same frequency as actions such as walking and breathing ${ }^{57}$ and could best be described as a lifestyle choice, rather than a major life activity. ${ }^{58}$ More recently, however, the US Supreme Court held in Bragdon v. Abbott that asymptomatic HIV positive status does constitute a disability under the ADA and that reproduction is a major life activity. ${ }^{59}$

This analysis suggests that, at least in some cases, infertility could be considered a disability. Although the details of the analysis under the ADA are not directly transferable to the Canadian context, the analysis and its conclusions may be useful. In Canada, the Charter itself provides no definition of physical or mental disability.

$52 \quad 29$ C.F.R. $\$ 1630.2(i)(1995)$

s 29 C.F.R. $\$ 1630$, App. (1995).

s4 Pacourek v. Inland Steel Co., 858 F. Supp. 1393 (N.D. III. 1994).

ss Erickson v. Board of Governors, 911 F. Supp. 316 (N.D. III. 1995).

s) Zatarain v. WDSU-Television, Inc., 881 F. Supp. 240 (E.D. La 1995) [hereinafter Zatarain]; Krauel v. Iowa Methodist Medical Center, 915 F. Supp. 102 (S.D. Iowa 1995) [hereinafter Krauel].

57 Zatarain, ibid. at 243: "A person is required to walk, see, learn, speak, breath [sic], and work throughout the day, day in and day out. However, a person is not called upon to reproduce throughout the day, every day." See also Krauel, ibid, at 106.

98 Krauel, ibid:: "Some people choose not to have children, but all people care for themselves, perform manual tasks, walk, see, hear, speak, breathe, learn and work unless a handicap or illness prevents them from doing so."

59 $118 \mathrm{~S}$. Ct. $2196(1998)$ at 2207. HIV status has also been recognized as a disability in Canada; see e.g. Canada (Attorney General) v. Thwaites [1994] 3 F.C. 38 (T.D.).
Definitions can be found in, for example, provincial human rights legislation or insurance documents. The Alberta Human Rights, Citizenship and Multiculturalism Act defines physical disability as: $:^{60}$

any degree of physical disability, infirmity, malformation or disfigurement that is caused by bodily injury, birth defect or illness and, without limiting the generality of the foregoing, includes epilepsy, paralysis, amputation, lack of physical co-ordination, blindness or visual impediment, deafness or hearing impediment, muteness or speech impediment, and physical reliance on a guide dog, wheelchair or other remedial appliance or device.

Given that the list of examples is not exhaustive, infertility could be included within the broad definition of "any degree of physical disability, infirmity ... that is caused by bodily injury, birth defect or illness," although it might also be argued that infertility is not analogous to the examples given and therefore should not be covered.

The precise scope of disability covered in each piece of legislation or legal instrument may depend on the context and intent of the provision: for example, the concept of disability may be linked to one's ability to work in contexts where the provision relates to benefits or other compensation flowing from one's inability to work. In the context of human rights legislation and the Charter, however, the definition should not be unnecessarily limited: ${ }^{61}$

An important factor in determining whether a particular condition amounts to a disability is the principle that Charter guarantees should be given a broad and liberal construction, and not be interpreted in an unduly technical, contorted or restrictive manner. Thus, if a court is in doubt as to whether a particular condition counts as physical disability, it

60 R.S.A. 1980 , c. H-11.7, s. 38(1)(i).

61 M. D. Lepofsky and J. E. Bickenbach, "Equality Rights and the Physically Handicapped" in A. F. Bayefsky and M. Eberts, eds., Equality Rights and the Canadian Charter of Rights and Freedoms (Agincourt, Ont.: Carswell, 1985) 323 at 345. This chapter contains a very useful discussion of the definition of physical disability at 343-46. 
should resolve its doubt in the plaintiff's favour. Having done so, the court ought to turn to the core question under s. 15 , namely, whether the Charter plaintiff was denied equality rights on account of his or her physical disability.

There are sufficient indications, based inter alia on the ADA jurisprudence, that infertility could be considered a disability. Given the need for a broad, purposive interpretation of Charter provisions, physical disability should include infertility for the purposes of section 15. Bateman J.A.'s refusal to recognize infertility as a physical disability or analogous ground was largely based on a perceived need to narrow the ambit of potential claims in health care: ${ }^{62}$

To create an analogous ground in the broad sense suggested by the appellants would unreasonably expand the ambit of s. 15(1) ... When a procedure or treatment is not funded some person or group will inevitably suffer disadvantage. Every such decision would conceivably be a distinction based upon a new analogous ground or, in the appellants' submission, a "disability."

These concerns, however valid they may be, can be better addressed in the later stage of the analysis, in considering whether the denial of funding or other distinction is discriminatory within the meaning of section $15(1)$ or whether it can be justified under section 1 .

\section{IS THE DENIAL OF FUNDING FOR IVF AND ICSI DISCRIMINATORY?}

Assuming, then, that the denial of funding for IVF and ICSI results in differential treatment based on an enumerated or analogous ground, it remains to be determined whether that differential treatment constitutes discrimination. It is well established that not every distinction on an enumerated or analogous ground is discriminatory ${ }^{63}$ and that "the existence of a conflict between an impugned law and the purpose of section $15(1)$ is essential in order to found a discrimination

62 Cameron (CA), supra note 1 at 678.

63 See e.g. Law, supra note 4 at 18, citing numerous other statements of this point by the Supreme Court of Canada. claim." purpose as follows: ${ }^{65}$

the purpose of s. 15(1) is to prevent the violation of essential human dignity and freedom through the imposition of disadvantage, stereotyping or political or social prejudice, and to promote a society in which all persons enjoy equal recognition at law as human beings or as members of Canadian society, equally capable and equally deserving of concern, respect and consideration.

A law will violate this purpose where differential treatment on the basis of an enumerated or analogous ground "has the effect of perpetuating or promoting the view that the individual is less capable, or less worthy of recognition or value as a human being or as a member of Canadian society." by reference to contextual factors such as the presence of pre-existing disadvantage, the relationship between the grounds and the claimant's characteristics or circumstances, the law's ameliorative purpose or effects and the nature of the interest affected. ${ }^{67}$

Chipman J.A. applied the analytical framework set out in Law and held that the differential treatment in this case did constitute discrimination in this sense. The focus of his analysis is on the first contextual factor, pre-existing disadvantage. ${ }^{68}$ Ample evidence was brought to show that infertile persons have historically suffered and continue to suffer a degree of disadvantage in society. However, Chipman J.A.'s further conclusion that the denial of funding for these procedures "perpetuates the view that [the infertile] are less worthy of recognition or value" and "touches their essential dignity and self-worth" ${ }^{\prime 9}$ is problematic. It is important to note that in Law, Iacobucci J. specifically warned that he was not suggesting "that the claimant's association with a group which has historically been more disadvantaged will be conclusive of a violation under section 15(1), where differential treatment has been established. ... There is no principle or evidentiary presumption that differential treatment for historically disadvantaged persons is discriminatory." ${ }^{, 70}$ Chipman

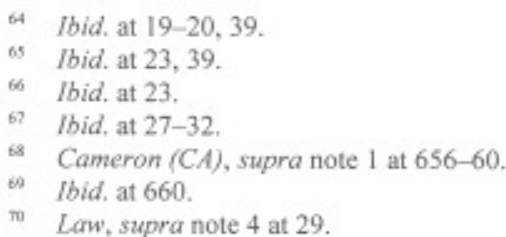


J.A. does appear to rely on such a presumption, however. ${ }^{71}$ Furthermore, although the analysis includes a subjective element since the matter must be considered from the perspective of the claimant, "a court must be satisfied that the claimant's assertion that differential treatment imposed by legislation demeans his or her dignity is supported by an objective assessment of the situation." ${ }^{n 2}$ Chipman J.A.'s suggestion that an infertile person's sense of dignity and self-worth would be affected by the exclusion of IVF and ICSI is not supported by any objective factors. His analogy to the Vriend case, ${ }^{73}$ which dealt with the denial of basic human rights protection for gays and lesbians, is a dubious one in this context.

Faced with a growing array of treatments and limited (even shrinking) budgets, governments will have to make difficult decisions about payment for treatments. They do not, of course, have unlimited discretion in making these decisions and, in some cases, a policy choice may be properly said to be discriminatory: ${ }^{74}$

If, for example, it was the government's policy not to fund any medical services for the infertile (assuming them to be "disabled"), without regard to the nature of the service, it is likely that such a policy would be seen to promote the view that such persons were less worthy of recognition or value as a human being or as a member of Canadian society. Such would likely be the case, as well, with a policy that denied all medical treatment specific to gays and lesbians or all treatments which only women required. Regardless of the language of such policy, if its existence led inevitably to the conclusion that its effect was to send a message that these persons or groups were less worthy of recognition it would likely not withstand the s. 15(1) scrutiny and require justification under s. 1 .

As noted earlier, it seems unlikely that the denial of public health insurance funding for a treatment judged not to be medically necessary could be considered to be discrimination. On the other hand, denial of funding for

\footnotetext{
Cameron (CA), supra note I at 656,660 .

Law, supra note 4 at 26 .

Vriend v. Alberta, [1998] I S.C.R. 493.

Cameron (CA), supra note 1 at 683-84.
}

a treatment which is medically necessary and for which there are no significant concerns with respect to effectiveness or risk, might be vulnerable to a charge of discrimination. It cannot be the case, however, that whenever funding is denied for a treatment or procedure that is specifically relevant to or required by persons with a particular medical condition or disability, the mere fact of the denial will be sufficient for a finding of discrimination. There may be grounds for a claim that the provincial government is in violation of its obligations under the Canada Health Act to provide comprehensive health services. ${ }^{75}$ It is perhaps unfortunate that these obligations cannot be enforced by individuals under the current system, but this does not justify a claim that the denial is discriminatory unless the indicia of discrimination as set out in Law are indeed present.

\section{Section 1}

Chipman J.A. found that there was discrimination contrary to section $15(1)$, but that it could be justified under section 1 of the Charter. Although I disagree with his conclusion on section $15(1)$, it is important to consider the section 1 analysis because it has potentially serious implications. Assuming, then, that the denial of funding could be described as discrimination on the ground of physical disability, can it be justified under section 1 ?

The primary, if not exclusive, basis for Chipman J.A.'s finding of section 1 justification was the existence of "extreme" budgetary pressures on the Nova Scotia health care system. Although there is brief mention of "protection of those receiving the procedures from the potential harms of treatments not adequately proven safe" objective, the analysis turns entirely on the question of allocation of scarce resources. Although Supreme Court jurisprudence suggesting that "financial considerations alone may not justify Charter infringements" $" 7 ?$ is acknowledged, that is essentially what is permitted by Chipman J.A.'s analysis. Great emphasis is placed on the need to show deference to decisions involving

\footnotetext{
See supra note 38.

Cameron (CA), supra note 1 at 664.

7 Ibid, at 663, quoting Eldridge, supra note 3 at 685 , which in turn refers to Schachter v, Canada, [1992] 2 S.C.R. 679 at 709.
} 
resource allocation and the possibility of incremental measures. The government is merely required to "show a reasonable basis for concluding that it has complied with the requirement of minimal impairment in seeking to attain the objectives."

Similar issues were raised in the Eldridge decision, ${ }^{79}$ but because the denial of funding for sign language interpreters, which was dealt with in that case, so clearly failed the minimal impairment test, there was no need to confront the other aspects of the section 1 analysis. La Forest J., writing for the Court, assumed, without deciding, that controlling health care expenditures could be a pressing and substantial objective for the purposes of section $1 .{ }^{80} \mathrm{He}$ also found it "unnecessary to decide whether in this 'social benefits' context, where the choice is between the needs of the general population and those of a disadvantaged group, a deferential approach should be adopted."

The Supreme Court has thus left the door open for a justification of discriminatory treatment in health care or other social services based solely on reasons of financial constraints, subject to rational connection, minimal impairment and proportionality tests. In this case, where the government's argument on minimal impairment is much stronger, ${ }^{82}$ these questions must be squarely addressed.

Since Canadian courts have often referred to international human rights law to assist in assessing "reasonable limits" objectives" 84 under the Charter, it may be illuminating to note the manner in which similar questions are dealt with in the international human rights law literature. The right to health and other social rights are guaranteed in a number of international legal instruments, including the International Covenant on

7 Ibid. at 664

\% Supra note 3.

so lbid at 685 .

s1 Ibid. at 686 .

82 Indeed, comments in Eldridge (ibid. at 689) which contrast the facts in that case with a claim "that the government provide them with a discrete service or product, such as hearing aids, that will help alleviate their general disadvantage," seem to suggest that the latter might satisfy the minimal impairment test.

is See W. A. Schabas, International Human Rights Law and the Canadian Charter, $2^{\text {nd }}$ ed. (Scarborough, Ont.: Carswell, 1996) at 114-18.

s4 See ibid at 125-28.
Economic, Social and Cultural Rights. ${ }^{85}$ Predictably, financial constraints and difficulties of resource allocation are commonly raised as objections to the fulfilment of states' obligations under these instruments. The ICESCR accommodates these concerns by providing that states undertake to "take steps ... to the maximum of its available resources, with a view to achieving progressively the full realization of the rights recognized in the present Covenant." ${ }^{86}$ This does not mean that states can defer progress immediately, pleading a lack of resources; they are required to begin immediately to take steps toward the fulfilment of rights. ${ }^{87}$ They must also make effective use of the resources that are available ${ }^{88}$ and give due priority to the realization of rights when allocating resources. ${ }^{89}$ However, states are not expected to achieve the impossible when only limited resources are available. The right to health, specifically, is framed as the right to the "highest attainable standard of physical and mental health."

However, the ICESCR also requires states to "guarantee that the rights enunciated in the present Covenant will be exercised without discrimination of any kind." ${ }^{\text {"W] }}$ These obligations of non-discrimination, unlike the substantive rights in the Covenant, are not to be achieved progressively but rather impose immediate obligations on the state to fulfil rights - to whatever degree they are fulfilled - without discrimination. ${ }^{92}$

ss International Covenant on Economic, Social and Cultural Rights, 16 December 1966, 993 U.N.T.S. 3; Can. T.S. 1976 No. 46 [hereinafter ICESCR].

16 Ibid., art. 2(1), emphasis added.

17 See e.g. Limburg Principles on the Implementation of the International Covenant on Economic, Social and Cultural Rights, UN Doc. E/CN.4/1987/17, Annex, reprinted in (1987) 9 Hum, Rts. Q. 122 [hereinafter Limburg Principles] at para. 21.

28 Ibid. at para. 23, 27.

so lbid. at para. 28 .

90 ICESCR, supra note 84, art. 12(1).

91 Ibid, art. 2(2). The list of enumerated grounds does not include disability, but the list is not exhaustive as it includes "other status" (see also Limburg Principles, supra note 86, para. 36). The Committee on Economic, Social and Cultural Rights has stated that this requirement, "based on certain specified grounds 'or other status' clearly applies to discrimination on the grounds of disability"; Committee on Economic, Social and Cultural Rights, "Persons with disabilities" (General Comment No. 5), 9 December 1994, UN Doc. E/1995/22 at para. 5.

92 Committee on Economic, Social and Cultural Rights, "The nature of States parties obligations (art. 2, para. 1 of the Covenant) ${ }^{h}$ (General Comment No. 3), 14 December 1990, UN Doc. E/1991/23 at para. 1: "while the Covenant provides for progressive realization and acknowledges the constraints due to the limits of available resources, it also imposes various 
This approach to the analysis is compelling, since the notion that it could be reasonable in a free and democratic society to make one group, especially a disadvantaged group, bear a disproportionate share of the burden in the event of resource scarcity seems to run contrary to the basic principles of justice and fairness that the Charter was designed to protect. If a denial of funding truly is discriminatory, it is difficult to accept that it could be justified on the sole basis of financial restrictions. However, the decision in this case adopts this approach and the Supreme Court of Canada has certainly not foreclosed the possibility of allowing such a justification.

\section{CONCLUSION}

This brief analysis has attempted to highlight the importance of the issues in this case which raise fundamental questions of Charter interpretation and the legal restrictions on resource allocation decisions. As of the date of writing, the appellants were awaiting the outcome of their application for leave to appeal to the Supreme Court of Canada. ${ }^{93}$ If leave is granted, the Supreme Court's decision could provide much-needed guidance in this area.

\section{Barbara von Tigerstrom}

Health Law Institute, Faculty of Law, University of Alberta.

This work is part of an ongoing project of the Health Law Institute to address legal issues in health law reform. The support of this project by the Alberta Law Foundation is gratefully acknowledged. The author would also like to thank Timothy Caulfield and Pat Nugent for their helpful comments on an earlier draft of this article.

\section{REVIEW OF CONSTITUTIONAL STUDIES / REVUE D'ÉTUDES CONSTITUTIONNELLES}

\author{
VOLUME 5 NUMBER 1 (1999)
}

Contributors include:

\author{
JUST WORDS AND SOCIAL JUSTICE \\ Keith Ewing
}

\section{CHALLENGING ELECTORAL BOUNDARIES UNDER THE CHARTER: JUDICIAL DEFERENCE AND BURDEN OF PROOF Ronald E. Fritz}

\author{
THE CIVIL SOCIETY AND ITS ENEMIES: \\ THE CASE OF ISRAEL \\ Michael Keren
}

\section{EQUALITY JURISPRUDENCE: THE ORIGIN OF DOCTRINE IN THE SOUTH AFRICAN CONSTITUTIONAL COURT Justice Albie Sachs}

$\operatorname{cosT}^{*}$

Subscription to
Review of Constitutional Studies
GST applicable to
Canadian subscriptions (7\%)
For further information, contact:
Centre for Constitutional Studies
Fax: (780) 492-4924;
Telephone: (780) 492-5681;
e-mail: curquhar@law.ualberta.ca

$\$ 55.00$

obligations which are of immediate effect ... One of these ... is the 'undertaking to guarantee' that relevant rights 'will be exercised without discrimination."' See also Y. Klerk, "Working Paper on Article 2(2) and Article 3 of the International Covenant on Economic, Social and Cultural Rights" (1987) 9 Hum. Rts. Q. 250; Limburg Principles, supra note 86 at para. 35 .

93 Application for leave to appeal was filed on 9 November 1999. Supreme Court of Canada, Bulletin of Proceedings (19 November 1999). 